\title{
An Archaeological Survey of a Proposed Water Main in Val Verde County, Texas
}

Joseph H. Labadie

Follow this and additional works at: https://scholarworks.sfasu.edu/ita

Part of the American Material Culture Commons, Archaeological Anthropology Commons, Environmental Studies Commons, Other American Studies Commons, Other Arts and Humanities Commons, Other History of Art, Architecture, and Archaeology Commons, and the United States History Commons

Tell us how this article helped you.

This Article is brought to you for free and open access by the Center for Regional Heritage Research at SFA ScholarWorks. It has been accepted for inclusion in Index of Texas Archaeology: Open Access Gray Literature from the Lone Star State by an authorized editor of SFA ScholarWorks. For more information, please contact cdsscholarworks@sfasu.edu. 
An Archaeological Survey of a Proposed Water Main in Val Verde County, Texas

Creative Commons License

(c) $)(1)$ (9)

This work is licensed under a Creative Commons Attribution-NonCommercial 4.0 International License 
AN ARCHAEOLOGICAL SURVEY OF A PROPOSED WATER MAIN IN VAL VERDE COUNTY, TEXAS

\author{
Joseph H. Labadie
}

Project Performed for the Department of the Army, Albuquerque District, Corps of Engineers Under Contract Number DACW47-84-M-0586

Center for Archaeological Research The University of Texas at San Antonio ${ }^{8}$

Archaeological Survey Report, No. 158 
A 1 ist of publications offered by the Center for Archaeological Research can be obtained by sending $\$ 1.00$ to the Center for Archaeological Research, The University of Texas at San Antonio, San Antonio, Texas 78285. 


\section{ABSTRACT}

During September 11-13, 1985, the Center for Archaeological Research, The University of Texas at San Antonio, conducted an archaeological survey of a proposed water main pipeline for the Department of the Army, Albuquerque District, Corps of Engineers. The pedestrian survey identified one archaeological site (41 VV 810) that produced no temporal1y diagnostic artifacts. Construction of the water main will not adversely affect the site. 


\section{TABLE OF CONTENTS}

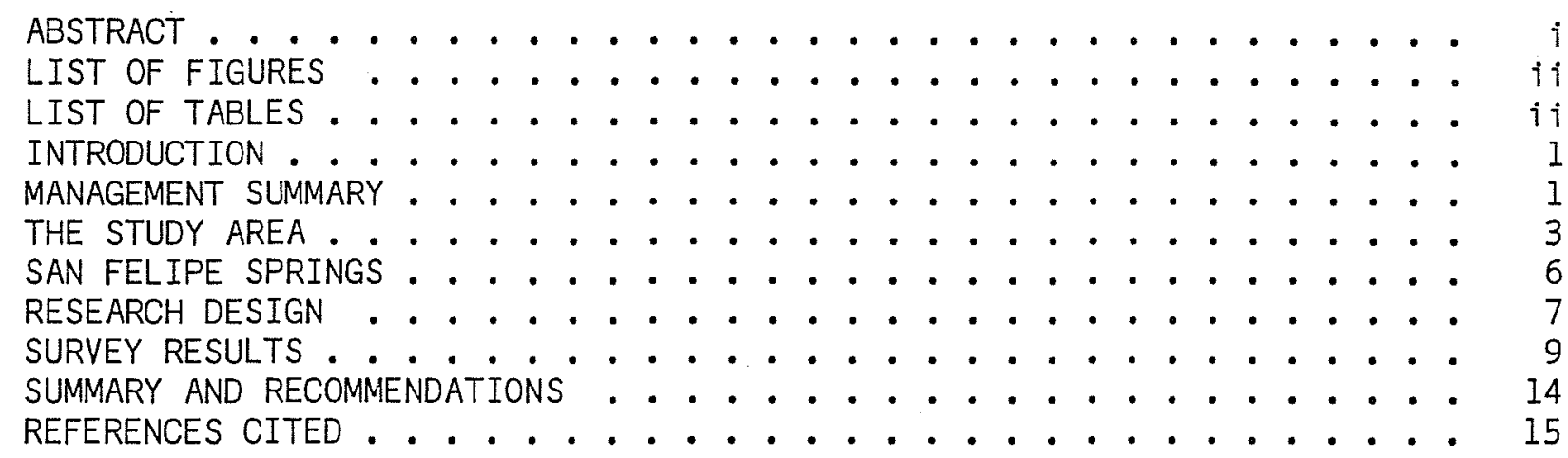

\section{LIST OF FIGURES}

1. Location of the Proposed Route and Survey Transect for the Laugh1 in Air Force Base Water Main Project . . . . . . . . . . . . 2

2. Relationship of Soils and Topography in the 01mos-Acuna-Coahuila Map Unit . . . . . . . . . . . . . . . . . . . . . . 5

3. Vertical Cross Section of the 5.6-Mile Survey Transect, Illustrating the Location of the Tobosa and Coahuila Soil Series $\quad 8$

4. Site Plan Map of 41 VV 810 in Project Map Section 2-A . . . . . . . 11 5. Location of Isolated Surface Finds Within Project Map Section 4-B . 13

\section{LIST OF TABLES}

1. Engineering Data Used to Determine the Infield Survey Transect for the Proposed Route for the Laughi in Air Force Base Water Main Project ......................... 


\section{INTRODUCTION}

During September 11-13, 1985, the Center for Archaeological Research (CAR), The University of Texas at San Antonio (UTSA), carried out a reconnaissance level cultural resource survey within a water main right-of-way between San Felipe Springs in Del Rio to Laughl in Air Force Base, Val Verde County, Texas. The purpose of the pedestrian survey was to carefully examine the ground surface for any evidence of archaeological or historical resources along the entirety of the proposed waterl ine route.

The survey was done under contract with the Department of the Army, Albuquerque District, Corps of Engineers (DD Form 1155, dated September 24, 1984). The investigations followed the guidelines suggested in the "Council of Texas Archeologists Performance Guidelines" (CTA 1981) and the Corps of Engineers Scope of Services as closely as possible. Where this was not possible, it has been noted in this report of investigations.

The field work was conducted by CAR staff archaeologists George H. Deaton and Joseph H. Labadie (field director and author), under the supervision of Dr. Thomas R. Hester, principal investigator and CAR director, and Jack D. Eaton, co-principal investigator and associate director.

Prior to the current survey, no systematic archaeological investigations had been made within the survey transect except for the area within the San Fel ipe Creek watershed (Prewitt and Dibble 1974). The Prewitt and Dibble survey recorded 14 prehistoric sites, al1 of which are located on properties north of the San Felipe Country Club (4I VV 431-41 VV 443 and 41 VV 445). In the 1 ate $1920 \mathrm{~s}$ and early 1930s, Wil $1 \mathrm{iam}$ F. Boggess, Jr. (n.d.), col lected a number of artifacts from site 41 VV 444 near the main outlet of San Felipe Springs (Prewitt and Dibble 1974:I); this site was not within the current survey transect.

\section{MANAGEMENT SUMMARY}

A reconnaissance level survey was requested by the Albuquerque District of the Department of the Army, Corps of Engineers as part of their planning for the installation of a 16-inch diameter waterline that will supply Laughlin Air Force Base with water from San Felipe Springs (Fig. 1); these springs have a 90 million gallon daily flow. The waterline will be placed underground and wi11 range in depth from 2.8 to 3 feet below the modern-day ground surface.

Prior to the commencement of the pedestrian portion of this survey, a short meeting took place between CAR archaeologists Joe Labadie and George Deaton and personnel from the 47th Civil Engineering Squadron at Laugh 1 in Air Force Base. Ms. Gloria Hernandez verified that rights-of-entry had been obtained from al1 landowners within the survey transect and provided a detailed map denoting property boundaries. Ist Lt. Paul Pinnsenault provided a "final version" set of waterline project maps drawn by the Corps of Engineers which included photogrametric and topographic maps that depicted the entire 5.6mile survey transect (ca. 67.8 acres of survey area). Laughlin personne1 stated that they did not know when, or by whom, the actual route had been 
This page has been

redacted because it

contains restricted

information. 
surveyed in the field. They could not verify if the proposed route depicted on the maps had been marked by surveyor's pins, wooden stakes, or other types of infield identifications. They stated that the Albuquerque District had handled nearly all phases of the planning and engineering for the project. Fol 1 owing the meeting. AIC Scott Moore accompanied the CAR survey team to assist in locating the proposed waterline route within base property and to act as the base representative in dealing with private property owners.

The maps provided noted that the proposed route was not designed in a perfect 1 y straight 1 ine between San Fel ipe Springs and Laugh 1 in Air Force Base, but actually consisted of sections of pipeline, ranging in length from 40.0 to 5245.27 feet, which a 17 joined at slightly different angles. At each of the junction points, the maps noted that auger tests had been dril led by the Corps of Engineers. Once the survey began, it was immediately obvious that no infield identifiers marked the waterline route or junction points. In view of the number of angles and the range of distances involved between junction points on the maps, it was decided that a second meeting with the Laughl in Air Force Base personnel was in order before proceeding.

At this second meeting, we discussed the potential impacts produced by the unmarked survey transect on the Scope of Services agreement with the Corps of Engineers. It was agreed that lst Lt. Pennsenault would convert engineering data on the maps to azimuths and distances between junction points (indicated as stations on $T a b l e ~ 1)$ and that the survey would proceed using a lensatic compass. The survey would be expanded to 100 feet either side of the center1 ine (from the original 25 feet) in selected places to allow for any potential errors in calculations or compass readings. The exact route of the field survey would be marked by orange flagging tape to facilitate any future relocation of the route surveyed by the CAR-UTSA team. It is felt that this change from the original Scope of Services did not bias the survey results.

\section{THE STUDY AREA}

The area of study consisted of a 50-foot-wide water main right-of-way that began at San Felipe Springs in Del Rio and extended ca. 5.6 miles east to Laughlin Air Force Base (Fig. 1). Research at the Texas Archeological Research Laboratory (TARL) in Austin. Texas, disclosed that no prehistoric or historic archaeological sites had been recorded within the survey transect.

The survey transect is relatively flat and exhibited very 1 ittle topographic relief across its entirety (960-1080 feet above ms 1) and was roughly oriented east-west off of magnetic north. The transect is located in part of what is known as the 01 mos-Acuna-Coahuila soil map unit as defined by the Soil Conservation Service (1982:11). This type of soil makes up about 8\% of Val Verde County and is spatialiy 1 imited to the southeast portion of the county. Soil map units consist of broad areas that have a distinctive pattern of soils, topographic relief, and drainage patterns. Each map unit on the general soil map for $V a l$ Verde County is a unique natural 1 andscape (Fig. 2). The 01 mos-Acuna-Coahuila soil map consists of nearly level to sloping soils on a series of old outwash deposits on nearly level to sloping $\left(0-8^{\circ}\right)$ valley fil $1 \mathrm{~s}$ and low hills. 
TABLE 1. ENGINEERING DATA USED TO DETERMINE THE INFIELD SURVEY TRANSECT FOR THE PROPOSED ROUTE FOR THE LAUGHLIN AIR FORCE BASE WATER MAIN PROJECT

Linear distance and magnetic bearing Azimuth between auger holes Stations Distance (feet) Degrees Minutes Seconds

\begin{tabular}{lcccc}
\hline$A^{*}-B$ & 145.00 & 137 & 10 & 28 \\
B-C & 440.61 & 225 & 16 & 38 \\
C-D & 557.44 & 254 & 6 & 38 \\
D-E & 918.13 & 238 & 10 & 48 \\
E-F & 3330.63 & 266 & 33 & 24 \\
F-G & 5245.27 & 280 & 52 & 53 \\
G-H & 4907.05 & 277 & 25 & 30 \\
H-I & 1336.60 & 272 & 34 & 24 \\
I-J & 541.60 & 280 & 44 & 59 \\
J-K & 776.71 & 278 & 30 & 58 \\
K-L & 771.97 & 289 & 50 & 37 \\
L-M (San Fe]ipe & 2267.73 & 304 & 55 & 25 \\
Springs) & & & & \\
\hline
\end{tabular}

Note: Auger holes (AH) were drilled by the Corps of Engineers prior to survey; their relative location can be found in Figure 3.

The azimuth between auger holes is calculated off of magnetic north. *The reservoir at Laugh 1 in Air Force Base is designated as "A" and is located at 40 feet. 


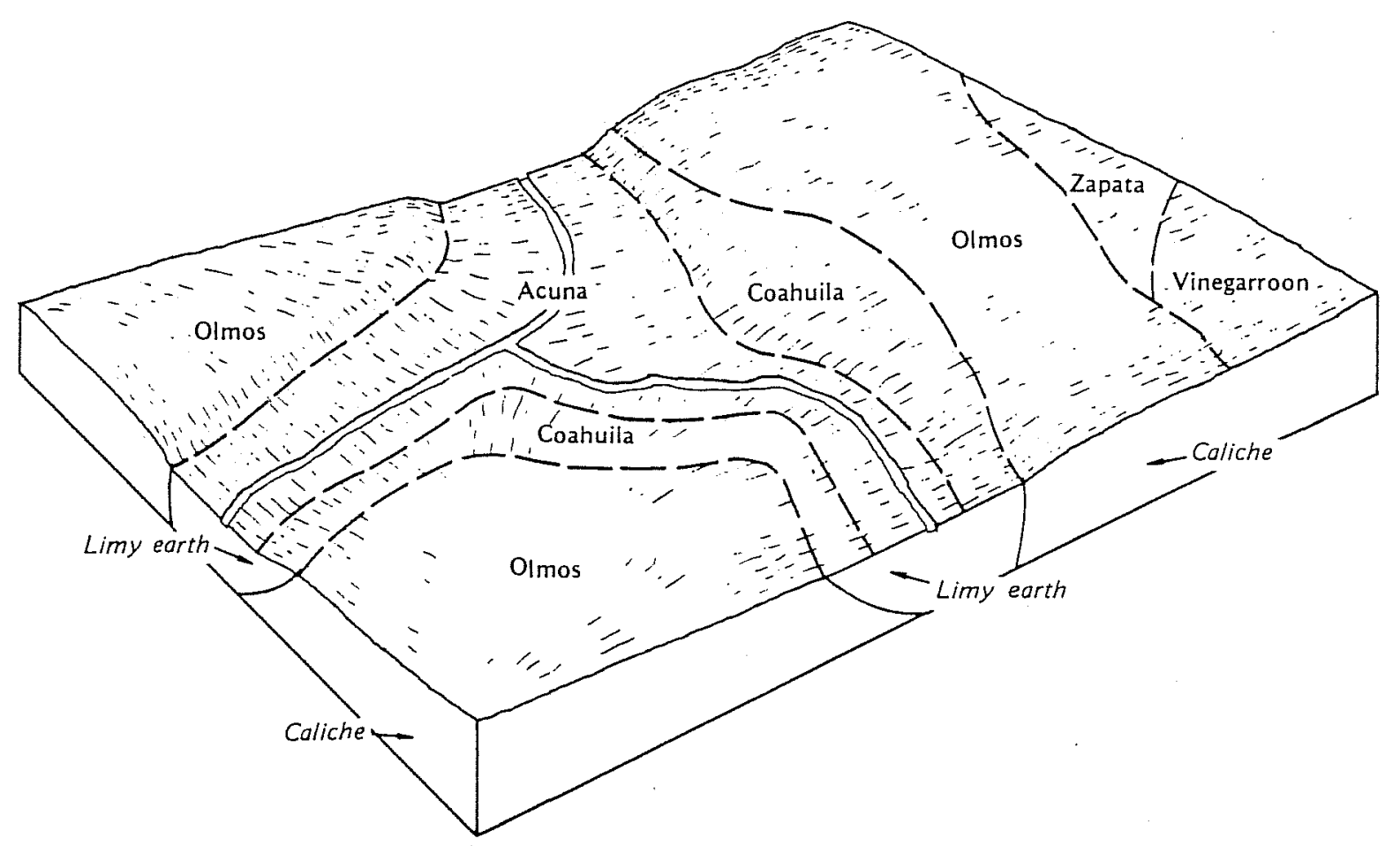

Figure 2. Relationship of Soils and Topography in the 01 mos-Acuna-Coahuila Map Unit. Taken from Soil Conservation Service (1982:5).

01 mos soils comprise the major soil type within the survey transect. They are the dominant soil type for the Bright and Honeycutt properties (Fig. 1 , map sections 2A-4A), and range from ca. 1055-1080 feet above ms 7 . The soils typically are moderately alkaline, brown, very gravelly loam about 18 inches (ca. $45 \mathrm{~cm}$ ) thick over indurated caliche that extends to a depth of 24 inches (ca. $60 \mathrm{~cm}$ ). Weak 1 y cemented caliche extends to a depth of 60 inches (ca. $1.5 \mathrm{~m}$ ) (Soi1 Conservation Service 1982:11).

Adjacent to and located on gentle slopes below the 01 mos soils are the Acuna soils at ca. 1030-1050 feet above msl. These soils typically have a surface 1 ayer of dark grayish brown silty clay about 18 inches thick. The upper 12 inches (ca. $30 \mathrm{~cm}$ ) of the subsoil is brown clay, the middle 30 inches (ca. $60 \mathrm{~cm}$ ) is pink silty clay, and the lower 12 inches is reddish yel $10 \mathrm{w}$ silty clay with soft masses of calcium carbonate. These soils are moderately a $1 \mathrm{ka} 1$ ine throughout (ibid.). Only a smal1 section of the survey transect consisted of Acuna soils, the western portion of the Bright property (Fig. 1 , map section 3-A).

The Coahuila soils are on valley fills and terraces of uplands. These soils were identified in several areas within the survey transect (Fig. 1 , map 
sections 4-A and 4-B) at about 1040-1060 feet above ms 1. These soils typically have a surface 7 ayer of grayish brown clay loam about 9 inches (ca. $23 \mathrm{~cm}$ ) thick. The upper 13 inches (ca. $33 \mathrm{~cm}$ ) of subsoil is pale brown silty clay loam, the next 11 inches (ca. $27 \mathrm{~cm}$ ) is pale brown silty clay loam, and the lower 29 inches $(\mathrm{ca} .78 \mathrm{~cm}$ ) is very pale brown silty clay with numerous soft masses of calcium carbonate. The soils are moderately alkaline throughout (Soil Conservation Service 1982:11).

Other less extensive components of the 01 mos-Acuna-Coahuila map group include the Felipe, Vinegarroon, Valverde, Tobosa, and Zapata soils. The bed of Zorro Creek consists of Tobosa soils, which are deep clays that occur on clay flats (Fig. I, map sections 4-A and 4-B). Tobosa soils were also isolated just south of the railroad tracks near Calavaras Creek (Fig. 1, map section 2-A). Felipe soils are 1 imited to the creek bed south of San Felipe Springs, just north of Highway 90 . The Zapata-Vinegarroon complex was 1 imited to the gentle slopes near Calavaras Creek (Fig. l, map section 2-A).

Vegetation within the survey transect was general1y sparse; two distinct floral communities were noted within the transect. In the upland areas (01mos-Coahuila-Acuna soil series), common elements of the floral community include acacia (blackbrush, quajil10, huisache, and catclaw), isolated mesquite, cedar, cenizo (purple sage), prickly pear, and Spanish dagger. In contrast, and spatially limited to the Tobosa and Coahuila soil series along Calavaras and Zorro Creeks, the floral communities consist of a sometimes dense coverage of medium-to-tal 1 grasses, whitebrush, and mesquite. The amount of available moisture is primarily responsible for the spatial distribution of vegetation within the survey transect.

The survey transect has seen differential 1 and-use practices during the 20th century. At present the transect evidences many different uses: active cultivation of Sudan grass and oats; pasturage for sheep, goats, cattle, and horses; recreational activities at the San Felipe Country Club; sanitary 1 and $i 11$ operations at Laugh 1 in Air Force Base; unimproved county and/or private roads; and a residential community. Modern land-use practices have badly disturbed any buried or surface prehistoric or historic sites in a large portion of the survey transect.

\section{SAN FELIPE SPRINGS}

San Felipe Springs consists of a group of 10 springs, Texas' fourth 7 argest set of springs (Brune 1981:452). The area around the springs is a significant resource particularly in the areas of agriculture and engineering.

The earliest historic mention of the springs by Europeans comes from the Gaspar Costano de Sosa Expedition of 1590 (National Register of Historic P1aces Inventory--Nomination Form. Item 8:2). By 1776, Spanish soldiers frequently camped at the springs while trailing marauding Apaches ( $i b i d$. ). By 1862, immigrants and settlers began making San Felipe del Rio their home. James $H$. Taylor is credited with having the first canal dug at the springs for agricultural purposes and grist and sugarcane milling operations. In 
1892, as much as 1250 hectares were being irrigated by waters from San Felipe Springs (Brune 1981:453).

Survey map section IA transects a portion of the San Felipe Springs area. The actual transect area has been total1y modified to an unknown depth by ground-leveling activities associated with the San Felipe Springs golf course. There is a high probability that buried historic and prehistoric cultural materials still exist given the known history of the springs. However, shovel testing across two active golf course fairways was not deemed appropriate at the time of this survey. This area should be further investigated once a firm construction date and plans have been established.

\section{RESEARCH DESIGN}

The research design for the reconnaissance level survey of the Laughlin Air Force Base water main project followed standard archaeological procedures and the Scope of Services agreement supplied by the Department of the Army, Albuquerque District, Corps of Engineers. Prior to the pedestrian survey, orthophotographic, topographic, and geologic maps of the survey transect were intensively studied for any surface indications of archaeological sites. Prehistoric occupation sites representing campsites and resource exploitation areas, commonly occur along creek banks and stream terraces throughout Texas (Hester 1980:57). These types of 7 andforms usua 71 y consist of distinctive soil zones, in this case, Tobosa and Coahuila series soils (Fig. 3 ). Three areas of relatively high archaeological potential were noted within the survey transect: (1) San Felipe Springs, (2) Calavaras Creek, and (3) Zorro creek. For these areas, the survey was expanded to 100 feet either side of the center 1 ine, thus enabling the survey crew to detect the often subt 1 e surface evidence indicating a probable site. Distance between surveyors ranged between 10 to $15 \mathrm{~m}$ in spacing. Several transects were required to survey the areas with a high cultural potential.

Any collection of prehistoric and historic artifacts was to be 1 imited to only temporally diagnostic artifacts, e.g., projectile points, historic and prehistoric ceramics; none were found during the survey. Al1 identified materials were photographed in situ, plotted on project maps, and recorded relative to the nearest construction station. Artifacts were recorded as either isolated finds (IOs) or as constituent components of a site.

Infield documentation of sites and isolated finds would include the definition of the areal coverage, site density, frequency and distribution of artifacts and/or features. If necessary, shovel tests would be employed to determine site depth. Sites were to be inconspicuously marked by meta 1 stakes and given temporary field numbers. All sites identified in the field would be further documented on the appropriate State of Texas site forms; permanent Smithsonian site numbers would then be assigned by the Texas Archeological Research Laboratory (TARL). 


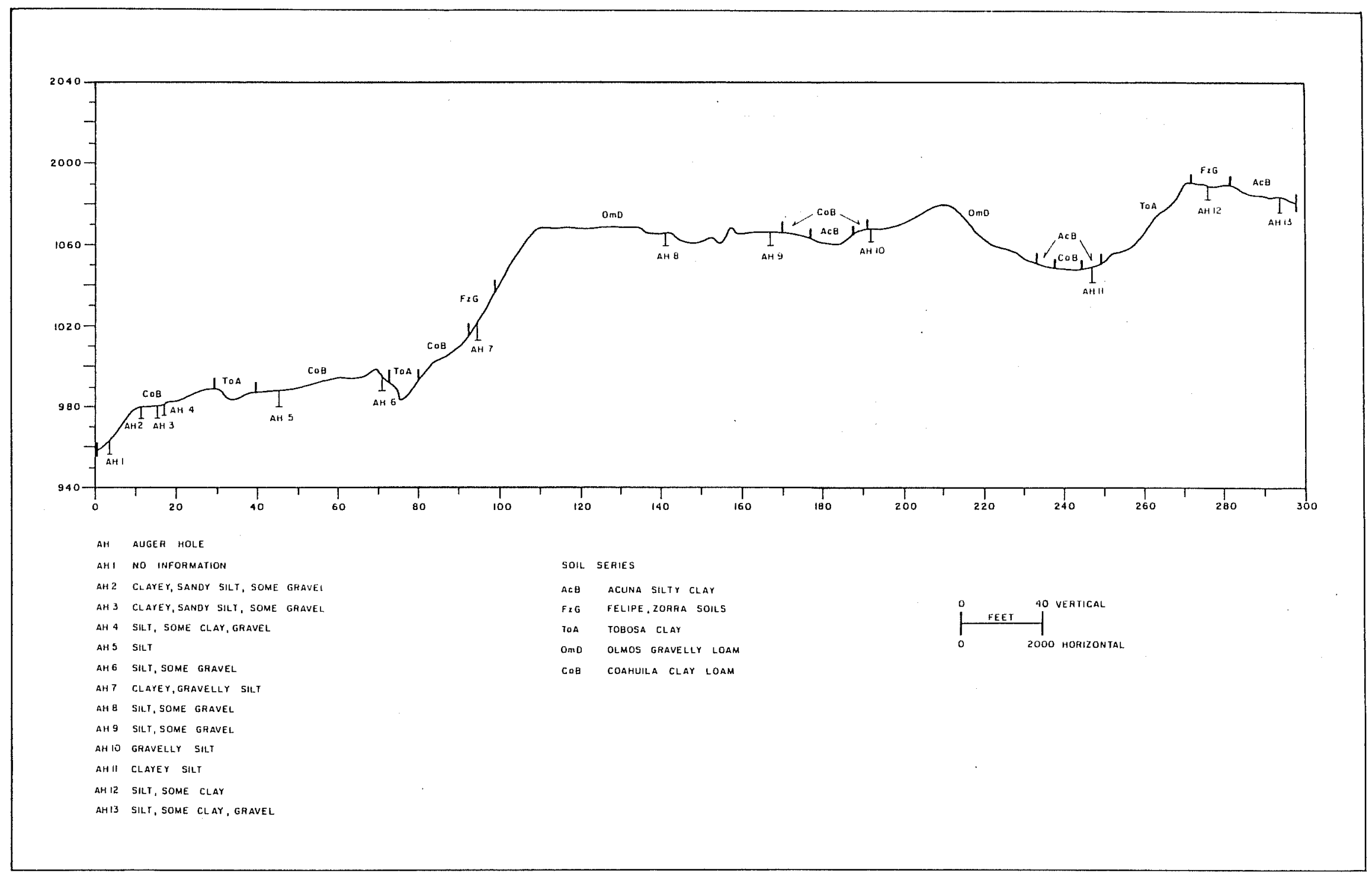

Figure 3. Vertical Cross Section of the 5.6-Mile Survey Transect, Il lustrating the Location of the Tobosa and Coahuila Soil Series. 


\section{SURVEY RESULTS}

The presentation of the survey results is divided according to map sections which correspond to the project maps supplied by the Department of the Army, Albuquerque District, Corps of Engineers and shown in Figure 1 of this report.

Section 1-A. Map section I-A contains the point of origin for the water main at San Felipe Springs which is located on the property of the San Felipe Country Club. The mean sea level (ms 1) elevation at the pumphouse is 950 feet ( \pm 2 feet). The waterline would begin at the existing pumphouse for the springs and head roughly southeast across several golf course fairways, a parking 1ot, and a gravel road, to Highway 90. After crossing under Highway 90, the water main would proceed east, paralleling the roadbed and a utility easement adjacent to a smal1 residential community (ca. 980 feet above ms 7 ).

Ground coverage, ranging from Bermuda grass, asphalt, and crushed 1 imestone and caliche roadbeds, totally obscured all the natural ground surface north of Highway 90 to the pumphouse; shovel testing was not deemed appropriate. South of the highway, modern ground leveling activities have totally disturbed the surface and subsoi 7 s.

Section 1-B. The survey transect of map section 1-B parallels the Highway 90 roadbed and shoulder. Construction and grading activities associated with the highway and utility easement have total1y disturbed $100 \%$ of the natural ground surface and subsoils within the survey transect in map section 1-B.

Section 2-A. The water main certerline will roughly parallel the northern side of existing roadbeds across the entirety of map section 2-A. Road grading activities associated with these roadbeds have disturbed a 11 the ground surface within ca. 15 feet either side of the roadbed centerline. Calavaras Creek is within this map section.

Calavaras Creek has a north-to-south water flow pattern which probably flows only after heavy downpours; the creek contained no running or standing water when surveyed. The creek bottom is filled with fine alluvial soils and relatively few gravels. The creek has wel1-defined cutbanks and makes a gentle angular meander just north of the gravel road before it enters a drain culvert which crosses under the road to the south.

Both sides of Calavaras Creek were intensively surveyed due to its relatively high cultural potential. The west side of the creek bank has been the repository for a large amount of residential and industrial trash dumping and is densely vegetated with a variety of tall grasses, weeds, sunflowers, and grass burrs. Inspection of the ground surface and erosional gullies failed to isolate any prehistoric or historic cultural indicators along the western bank of the creek.

The eastern creek bank is slightly steeper and roughly 10 feet higher due to the undercutting action of the creek's main watercourse. At the crest of the cutbank, the ground surface is relatively flat. Beginning roughly 100 feet east, and extending for another 125 feet east, the ground surface is totally unvegetated. It would appear that heavy equipment had removed fill dirt from 
this area fairly recently as evidenced by the unvegetated ground surface. At about 225 feet east of the creek bed, there is a small arroyo complex which extends up a 15-foot slope to a flat terrace. On this ridge top (Fig. 4), the remnants of a prehistoric open-air occupation site (41 VV 810 ) were identified.

The ground surface on this ridge top, rough 1 y 250 feet east of Calavaras Creek, consisted of a dense coverage of 1 ag gravels and is sparsely vegetated by short grasses, cenizo, and several pricky pear cacti. Soits are of the Coahuila clay loam series. A light scatter of 1 ithic debitage, consisting mainiy of primary and secondary hard-hammer percussion flakes, was scattered across an area rough 1 y north-south 90 feet by 110 feet east-west. Twentyseven chert $f l a k e s$ were found within this area, of which only three evidenced unifacial retouch along one or more lateral edges; none of the specimens was collected. This site did not contain any cultural features or temporal1y diagnostic artifacts. The ground surface of the site is eroded and badly deflated; cultural materials are 1 imited to the modern-day ground surface. A series of randomly $\mathrm{p} 1$ aced shovel tests failed to identify any debitage below ground surface. Sheetwash erosion has displaced materials down slope towards Calavaras Creek (west) and to within about 25 feet of the centerline of the gravel roadbed (south). Construction of the underground water main in this area should not adversely impact what is considered to be a badly disturbed site.

Section 2-B. The western two-thirds of the survey transect in map section 2$B$, owned by Marion Honeycutt, roughly coincides with the roadbed of an unimproved gravel road. The project maps indicate the water main centerline as running roughly parallel along the north side of this roadbed beginning in map section 2-A and continuing up the slope into map section 2-B. Road grading activities have badly disturbed the ground surface and subsoils roughly 15 feet either side of the roadbed centerline.

The eastern one-third of the survey transect contains several 1arge man-made circular features; map section $3-A$ contains nine more of these 1 arge features. The survey transect crosses in between and through several of the features. The features are described as near circular earthen berms, ca. 1015 feet in height and range 350-375 feet in diameter. They are very similar in appearance to earthen retainers normally found near above-ground petroleum or water storage tanks. Mesquite trees up to ca. five inches in diameter are on the slopes and ridges of these earthen berms. The earth used for their construction appears to have been bulldozed from the surrounding areas, thus destroying any archaeological sites that might have existed in this portion of the survey transect.

Section 3-A. Map section 3-A exhibits much the same geological, topographical, and floral conditions that are present in map section $3-B$. This portion of the survey transect ranges in elevation from 1060 to 1070 feet above ms 1, and the very gravel1y loam 01 mos soils cover the entirety of the transect. Mr. Taylor stated that this area has been used for rangeland and pasturage for his horses, sheep, goats, and cattle. He also stated that rainfall over the past few years has been minimal and that 1 ivestock has overgrazed this portion of the ranch, which has increased sheetwash erosion and aeolian deflation of the unvegetated ground surfaces. 
This page has been

redacted because it

contains restricted

information. 
Section 3-B. The ground surface for the survey transect within map section 3-B has very 1 ittle topographic relief (ca. 1050-1080 feet above ms 1). Surface vegetation is sparse. The only break in this otherwise flat featureless ridge top is of a low-lying area (ca. 350 feet across), which is a portion of a field under active cultivation (Sudan grass and oats). Sojls in this low-lying area are of the Coahuila series clay loams. Mr. Tom Taylor, leasee of the Myrtle Bright property, disclosed that this low area between two ridge tops concentrates available rain and effectively 7 imits sheetwash erosion and aeolian deflation in the general vicinity. Mr. Taylor further stated that he has leased the Bright property for over 27 years and has never found any type of prehistoric Indian artifact anywhere on the 1 and.

Section 4-A. Map section 4-A contains Zorro Creek, which is located along the western perimeter of Laughl in Air Force Base, and the eastern portion of the Myrtle Bright property. This area is a near featureless plain of alluvial soils, with the main water course for Zorro Creek identifiable by a sinuous concentration of eroded grave1s. Zorro Creek has no cutbanks or distinctive terraces adjacent to the main water course and would be subject to flash flooding in heavy downpours. The creek contained no running or standing water at the time of survey. Vegetal cover consists of waist-high grasses, weeds, sunflowers, prickly pear, and a few isolated mesquite thickets. The ground surface, consisting of Tobosa clayey soils, exhibited numerous cracks due to the 1 ack of moisture in the subsoils. Some of these cracks were measured to a depth of over eight inches $(c a .20 \mathrm{~cm})$.

On the western side of Zorro Creek, there is a gentle rise in elevation over the next one-quarter mile of the survey transect (ca. 1050-1080 feet above ms 1). Vegetal cover gradually thins out as one proceeds west from the creek bed. Tobosa series soils gradually fade into the Coahuila series soils with higher elevation; very grave 11 y 01 mos loams are present on and along the crest of the slope. The gravels present in the Zorro Creek bed have most probably eroded from this ridge 1 ine which roughly parallels the creek bed for some distance north of the survey transect.

The ridge top is located at the junction of map sections 4-A and 3-B, which has an absolute elevation of roughly $1080 \mathrm{~ms} 1$. Vegetation is 1 imited to isolated cenizo, acacia, prickly pear, and Spanish dagger; ground coverage is 1 imited to isolated patches of short grasses. Lag gravels, occurring in densities ranging from 1 ight scatters to near 1 ag gravel pavement, are distributed across the ridge top which continues for some distance west into map sections 3-B, 3-A, and the eastern portion of map section 2-B.

Section 4-B. Map section 4-B is Tocated on the eastern side of Zorro Creek and exhibits a gentle rise in elevation from west-to-east (1050-ca. 1090 feet above ms 1). The slope is vegetated with scrub brush, mesquite, and ta 11 grasses. The upper slope and ridge 1 ine is completely covered with piles of concrete, a 1 andfi 11 operation by Laugh 1 in Air Force Base that extends to within about 100 feet of a paved road.

Two isolated artifacts (IOS) were found within map section 4-B (Fig. 5). Both specimens are fragments of bifacially worked chert flakes. The color and diaphaneity of the chert is wel1 within the range of 1 ocally occurring chert grave1s. The specimens are too fragmentary to confidentiy determine if 
This page has been

redacted because it

contains restricted

information. 
they represent preforms or completed tool forms. Any exact temporal assignation for these artifacts would be tenuous, although both would appear to have prehistoric origins; neither of the artifacts was collected. The area in which these artifacts were found has been badly disturbed by bulldozing activities, which apparently involved the procurement of earthen fi] $]$ for use elsewhere on the base.

Section 5-A. The water main will enter Laughl in Air Force Base along the base's western property boundary (map section 4-A). The route will cross the eastern side of Zorro Creek and continue up a gentle slope through scrub brush (map section 4-B) until intersecting with a paved road about 425 feet west of the base's property disposal facility (map section 5-A). From this point, the proposed route will follow the existing roadbeds to a termination point at an above-ground reservoir. A thorough inspection of al 1 ground surfaces within map section 5-A failed to isolate any historic or prehistoric materials.

\section{SUMMARY AND RECOMMENDATIONS}

The reconnaissance level survey for the proposed Laugh 1 in Air Force Base water main was completed by a two-man survey team within the stipulated three-day period; roughly one and one-half days of the survey were conducted in intermittent thunderstorms. A Laughl in Air Force Base representative accompanied the survey team across nearly a 11 project map sections of the survey transect.

The project documented two isolated occurrences of prehistoric artifacts (neither was collected) and one badly eroded prehistoric site (4I VV 810); no historic materials were recorded within the survey transect. The majority of the survey transect evidences 20 th-century 1 and-use practices that would have badly disturbed (or totaliy destroyed) any surface or buried prehistoric or historic features or sites; thus no shovel tests were deemed appropriate.

The two isolated occurrences of prehistoric artifacts would normaliy suggest the existence of a site in the immediate vicinity of where they were found. However, the entire area has been bulldozed, and the soil has been removed for fill operations elsewhere on Laughlin Air Force Base. The original size and temporal placement of a site cannot be determined given the present conditions of the area.

A badly disturbed terrace site (4I VV 810), located on the eastern side of Calavaras Creek, was recorded during this survey. Artifactual materials were 7 imited to 1 ithic debitage; no temporally diagnostic artifacts were found. The ground surface of the site is unvegetated and has been subject to sheetwash erosion and aeolian deflation of surface soils. The probability of intact subsurface deposits is considered to be minimal.

There is a high degree of probability that buried cultural materials remain in the San Felipe Springs area (map section $1 \mathrm{~A}$ ). It is recommended that subsurface testing, to a minimum depth of three feet, be conducted prior to the commencement of construction once a firm date has been established. If this is not feasible, an archaeologist should be present during construction 
to monitor and prevent the potential destruction of any intact buried features.

The potential impact from the construction of the water main in the two prehistoric activity areas identified during this survey is considered to be minimal. These areas are not considered to be significant cultural resources in that they are not deemed potentially eligible for nomination to the National Register of Historic Places.

\section{REFERENCES CITED}

Boggess, W. F., Jr.

n.d. The William F. Boggess Collection, San Felipe Springs, Texas. Notes on fi]e, Texas Archeological Research Laboratory, Balcones Research Center, The University of Texas at Austin.

Brune, G.

1981 Springs of Texas. Vol. 1. Branch-Smith, Inc., Fort Worth.

Council of Texas Archeologists (CTA)

1981 Guidelines for Cultura 1 Resource Management Reports. Council of Texas Archeologists, News letter 5(2).

Hester, T. R.

1980 Digging Into South Texas Prehistory. Corona Publishing Company, San Antonio, Texas.

Prewitt, E. R. and D. S. Dibble

1974 The San Felipe Creek Watershed Project, Val Verde County Texas: An Archeological Survey. Texas Archeological Survey, The University of Texas at Austin, Research Report 40.

Soil Conservation Service (SCS)

1982 Soil Survey of Val Verde County, Texas. United States Department of Agriculture, Soil Conservation Service. 
